\title{
Covering Syria: Legal and Ethical Obligations of Journalists
}

\author{
Dan Saxon ${ }^{*}$
}

\section{Introduction: The right to know $v$ the protections of international law}

According to the Committee to Protect Journalists, today Syria is the most dangerous place in the world to practice the profession of journalism. At least 30 international and Syrian journalists have been killed covering the Syria conflict since March 2011. ${ }^{1}$ In addition, several international journalists apparently have been detained by the Assad regime and the units of the opposition armed groups known as the Free Syrian Army (FSA). The performance of the vast majority of the national and international journalists reporting from Syria since March 2011 has been invaluable and often courageous. Without their efforts, many of the historic and tragic events in Syria during the past two years would have remained unseen and unreported.

Nevertheless, during 2012, a small minority of journalists abused and exploited prisoners by 'interviewing' them under highly coercive circumstances. Several journalists-including those from major news networks-arguably violated moral principles underlying the legal obligations codified in international humanitarian law (IHL) and international human rights law (IHRL). Journalists

\footnotetext{
Assistant Professor at Leiden University College. During 2011 and 2012 the author was the Legal Adviser to the United Nations Independent International Commission of Inquiry for Syria. The views expressed in this article are the author's personal views, and do not necessarily reflect the views of the United Nations or the Commission of Inquiry for Syria.

${ }^{1}$ Committee to Protect Journalists, '30 Journalists Killed in Syria/Motive Confirmed', <http://cpj.org/killed/mideast/syria/> [accessed 5 January 2013].
}

Copyright $\odot$ the Author(s).

This work is licensed under a Creative Commons Attribution-NonCommercial-NoDerivs 3.0 License. 
enjoy important protections under $\mathrm{IHL}^{2}$ and $\mathrm{IHRL}^{3}$ and customary international humanitarian law provides that civilian reporters working in areas of armed conflict must be respected and protected as long as they do not take a direct part in hostilities. ${ }^{4}$ However, the purpose of this article is not to discuss the duties and obligations owed to journalists reporting from conflict zones like Syria. Rather, this article focuses on instances where journalists have ignored the protections due to prisoners of war (POWs) under IHL and IHRL in order to report about particular events in Syria. ${ }^{5}$

The creation and broadcast of these interviews raises important questions regarding the responsibilities of journalists in situations of armed conflict. Are journalists bound by the rules of IHL? Even if IHL does not impose obligations on journalists, to what extent should reporters, their editors and publishers be expected to understand these principles and rules? Finally (and most complex), how should journalists balance the tensions between the public interest in the free dissemination and reception of information about an ongoing war and the

${ }^{2}$ Under Article 4(A)(4) of the Third Geneva Convention Relative to the Treatment of Prisoners of War (GC III) of 12 August 1949, persons entitled to the protections of 'prisoners of war' include 'war correspondents ... provided that they have received authorization, from the armed forces which they accompany, who shall provide them for that purpose with an identity card'. Moreover, Article 79 of Additional Protocol I to the Geneva Conventions (AP I) provides that $[\mathrm{j}]$ ]ournalists engaged in dangerous professional missions in areas of armed conflict shall be considered as civilians within the meaning of Article 50, paragraph $1 \ldots$ without prejudice to the right of war correspondents ... provided for in Article 4A(4) of the Third Convention'. Thus, journalists enjoy all the protections afforded civilians by GC III and AP I. Nevertheless, two categories of journalists may be operating in an area of armed conflict: journalists accredited to the armed forces, and 'freelance' journalists. If they were captured, the former would be prisoners of war, while the latter would be civilians protected under GC IV and AP I. ICRC, Commentary to Additional Protocol I (1987), paras 3266 and 3271, <http://www.icrc.org/ihl.nsf/COM/470-750102?OpenDocument> [accessed 26 July 2013].

3 According to Article 19 of the Universal Declaration of Human Rights, "[e]veryone has the right to freedom of opinion and expression; this right includes freedom to hold opinions without interference and to seek, receive and impart information and ideas through any media and regardless of frontiers'.

${ }^{4}$ ICRC, 'Customary International Humanitarian Law Study', Rule 34, <http://www.icrc.org/cus tomary-ihl/eng/docs/v1_cha_chapter10_rule34> [accessed 26 July 2013]. My thanks to Robert Mahoney for this point.

5 This problem is not new. For example, during the first Gulf War in 1991, the Iraqi Government broadcast footage of captured and bruised British pilots giving 'humiliating statements'. M Meyer \& K Studds, 'Upholding Dignity and the Geneva Conventions: The Role of the Media in Protecting Prisoners of War and Civilian Security Internees Against Insults and Public Curiosity', 14 July 2006, 1, <http://www.icrc.org/eng/assets/files/other/amic_kevin_studds_final.pdf> [accessed 26 July 2013]. 
protections accorded to prisoners of war and other detainees of parties to an armed conflict?

Under the 1949 Geneva Conventions (which apply to international armed conflicts), prisoners of war must at all times be humanely treated. In addition, 'they must at all times be protected, particularly against acts of violence or intimidation and against insults and public curiosity'. ${ }^{6}$ Furthermore, persons holding prisoners of war must in all circumstances treat them with respect for their person and their honour. ${ }^{7}$ No form of coercion may be inflicted on prisoners of war to obtain from them information 'of any kind whatever." More recently, Article 45 of Additional Protocol I to the Geneva Conventions (AP I), applicable to international armed conflicts, grants the protections of 'prisoner of war' status to persons taking part in hostilities who fall into the power of an adverse party.

According to Additional Protocol II (AP II), similar protections are due to persons detained during non-international armed conflicts, such as the current civil war in Syria. For example, 'their physical or mental health and integrity shall not be endangered by any unjustified act or omission.' They must be treated humanely at all times and are entitled to respect for their person, honour, convictions and religious practices. ${ }^{10}$ Moreover, all wounded persons, 'whether or not they have taken part in the armed conflict, shall be respected and protected ${ }^{11}$ and no one should take advantage of their weakness in order to mistreat them or harm them in any way. ${ }^{12}$ Article 3 common to each of the four 1949 Geneva Conventions imposes a general duty to uphold the dignity of persons detained during internal armed conflicts. ${ }^{13}$ Stated more broadly, according to a rule of customary international humanitarian law, persons hors de combat must be treated humanely. ${ }^{14}$

${ }^{6}$ Art 13 GC III.

7 Art 14 GC III. When journalists are held as prisoners of war, this includes 'the right not to respond to interrogation'. W A Orme Jr, 'Journalists, Protection of,' in R Gutman \& D Rieff (eds) Crimes of War: What the Public Should Know (1999), 218.

8 Art 17 GC III.

9 Art 5(2)(e) AP II.

${ }^{10}$ Art 4 AP II.

${ }^{11}$ Art 7 AP II.

${ }^{12}$ ICRC, Commentary to Additional Protocol II, para 4635, <http://www.icrc.org/ihl.nsf/C OM/475-760012? OpenDocument> [accessed 26 July 2013].

${ }^{13}$ Meyer \& Studds, above n 5, 2.

${ }^{14}$ ICRC, 'Study of Customary International Humanitarian Law' , Rule 87, <http://www.icrc .org/customary-ihl/eng/docs/v1_cha_chapter32_rule87> [accessed 26 July 2013]. 
A strong public interest exists in protecting the scope of freedom of expression and the right to impart and receive information, ${ }^{15}$ in particular during an armed conflict where serious violations of human rights are committed by all belligerent parties. Nevertheless, the exercise of these rights carries special duties and responsibilities, which may require restrictions in order to protect the rights or reputations of others. ${ }^{16}$ For example, although a photograph or internet broadcast of a detained person may demonstrate that he or she is alive, the publicity may humiliate the detainee, place her or her family in danger, inflame ongoing tensions, etc. ${ }^{17}$ The U.K. Ministry of Defence prohibits the publication of images of detained persons 'either as identifiable individuals or which undermine their personal dignity.' ${ }^{\prime}$

Furthermore, under IHRL, the right to freedom of thought and expression includes the right not to speak. ${ }^{19}$ Indeed, in certain circumstances, coercing a detainee to make statements against her will may constitute cruel and inhuman treatment $^{20}$ and torture. ${ }^{21}$

Thus, during wartime, a tension exists between these liberties and the protections accorded by IHL and IHRL to prisoners of war and, in the case of non-international armed conflicts such as Syria, to persons detained by one of the belligerent parties. In this paper, I argue that, on occasion the international media in Syria has failed to properly balance these tensions, resulting in exploitation and abuse of prisoners of war. I will try to recommend some basic practices which may assist journalists to carry out their work consistent with the moral principles that underlie international law.

\footnotetext{
${ }^{15}$ Art 19(2), International Covenant on Civil and Political Rights (ICCPR), 16 December 1966, 999 UNTS 171; Article 10(1) European Convention for the Protection of Human Rights and Fundamental Freedoms (ECHR), 4 November 1950, 213 UNTS 222; Art 9, African Charter on Human Rights and Peoples' Rights (African Charter), 27 June 1981, 1520 UNTS 217.

${ }^{16}$ Art 19(3) ICCPR and 10(2) ECHR.

${ }^{17}$ Meyer \& Studds, 2, above $\mathrm{n} 13$.

${ }^{18}$ Ministry of Defence, 'Green Book-MOD Working Arrangements with the Media for Use Throughout the Full Spectrum of Conflict', Joint Service Publication 580, 31 January 2013, 18, <https://www.gov.uk/government/uploads/system/uploads/attachment_data/file/7 0682/greenbook_v8_20130131.pdf> [accessed 26 July 2013].

${ }^{19}$ Maritza Urrutia v Guatemala [2003] 103 IACHR 391, paras 99(c) and 103. This author is the husband of Maritza Urrutia.

${ }^{20}$ Ibid, para 88.

${ }^{21}$ Ibid, paras 91-94.
} 


\section{The Syria conflict and the potential for journalistic abuse}

On 15 February 2012, CNN broadcast a dramatic video of one of its journalists who had bravely slipped into Syria and made contact with a unit of the fledgling FSA. CNN explained that it was not publishing the exact location of its reporter, appropriately, 'because of concerns for her safety.' The title of the story was 'A Paid Killer in Syria Describes His Work'. ${ }^{22}$ The focus of the broadcast was the story told by a wounded Syrian Government agent detained somewhere in Syria by the FSA. The video broadcast shows portions of an interrogation conducted by one of the man's captors (with questions like 'Why are you killing us?') as well as a so-called 'interview' between the CNN reporter and the wounded and blind-folded detainee. With at least one of his armed captors present, the wounded man 'confessed' to the reporter that he had killed as many as 70 unarmed protesters on behalf of the Assad regime. The Syrian government had turned him, and others like him, into 'monsters', the man explained. The CNN journalist described how the detainee 'seemed ready to give up the names' of other persons who participated in the kidnapping of opposition members. 'There's no way to confirm [his] story', intoned the journalist, 'or be sure he hasn't been coerced. But now he is a bargaining chip. His captors intend to trade him for some of those abducted. ${ }^{23}$

A starker case of possible journalistic abuse of the principles underlying IHL was broadcast in October 2012 by Al Jazeera. In a story published on 17 October

${ }^{22}$ A Damon, CNN, 15 February 2012, < http://edition.cnn.com/2012/02/14/world/meast/syriapaid-killer/index.html> [accessed 26 July 2013].

${ }^{23}$ It is noteworthy to recall that at the time of the CNN interview in February 2012, there was still debate amongst international organizations and human rights groups as to whether the ongoing violence in Syria constituted an armed conflict for the purposes of applying IHL. There was little doubt that the intensity of the violence in Syria at that time, particularly in places like Homs, Idlib and parts of Damascus, rose to the level required to constitute an armed conflict. But the existence of the second requirement for determining the existence of a non-international armed conflict, the organizational level of the disparate FSA units, was much less clear. Human Rights Council, Report of the Independent International Commission of Inquiry on the Syrian Arab Republic, UN Doc A/HRC/19/69, 22 February 2012, para 13, http://www.ohchr.org/Documents/HRBod ies/HRCouncil/RegularSession/Session19/A-HRC-19-69.pdf. In fact, due to the difficulties of gaining access to many parts of Syria, international institutions-when making their own assessments of these issues-depended heavily on the observations of the limited number of journalists who succeeded to enter the country and monitor the organizational capabilities of the growing insurgency at that time. 
entitled 'Captured Syrian Pilot Speaks to Al Jazeera, ${ }^{24}$ a highly experienced correspondent 'interviews' a Syrian pilot who had been shot down over the town of al-Bab and captured by members of the FSA. One of the pilot's eyes was completely purple and swollen shut. As the filmed 'interview' progresses in the presence of the pilot's armed captors, the journalist explains to the public: 'We had no way to establish exactly how he had been treated before we got there, or what kinds of pressure he was under. But we wanted to hear his story.25 Amongst other questions, the correspondent asked the detainee: 'Did you understand ... that you were bombing civilians? ${ }^{26}$ The captured pilot appears frail and afraid in the video but the journalist explains that: 'Most think the pilot's innocence is feigned; a ploy to escape responsibility for his actions. ${ }^{27}$ The accusatory nature of the questions and the journalists' comments concerning the pilot's behaviour only increased his vulnerability.

On 7 December 2012, the BBC broadcast an encounter with six male prisoners detained at the Mezza Airbase in a detention centre operated by Air Force Intelligence, which, the BBC reporter mentioned, was 'Syria's most-feared intelligence service. ${ }^{28}$ The reporter described how 'human rights groups and former prisoners say torture happens here. ${ }^{29}$ In fact, the United Nations Commission of Inquiry for Syria and Human Rights Watch have documented the use of horrific torture against detainees at the Mezza Airbase prison since at least November $2011 .^{30}$ In the broadcast, Air Force Intelligence officials 'paraded' (the BBC's term) six male detainees for the cameras of the BBC and a film crew from Syrian State Television, the Assad Government's media outlet. Several of the men were elderly and 'all have confessed to being in Jihadist, Al-Qaida-style groups'. The passport of one of the men, an Algerian-French citizen, was filmed and broadcast, an act that documented his identity. This gentleman declined to

\footnotetext{
${ }^{24}$ A McNaught, Al Jazeera, 17 October 2012, <http://www.aljazeera.com/video/middleeast/ 2012/10/20121017194751288492.html> [accessed 26 July 2013].

${ }^{25}$ Ibid (emphasis added).

${ }^{26} \mathrm{Ibid}$

${ }^{27} \mathrm{Ibid}$.

28 'Syria Rebel-Held Areas Fear Attack', 7 December 2012, <http://www.bbc.co.uk/news/worldmiddle-east-20649670> [accessed 26 July 2013].

${ }^{29}$ Ibid.

${ }^{30}$ Human Rights Council, Report of the Independent International Commission of Inquiry on the Syrian Arab Republic, UN Doc A/HRC/S-17/2/Add.1, 23 November 2011, paras 61-72, <http://www.ohchr.org/Documents/Countries/SY/A.HRC.S-17.2.Add.1_en.pdf> [accessed 26 July 2013]; Human Rights Watch, 'Torture Archipelago: Arbitrary Arrests, Torture, and Enforced Disappearances in Syria's Underground Prisons Since March 2011' (2012), 56-62. $<$ http://www.hrw.org/reports/2012/07/03/torture-archipelago-0> [accessed 26 July 2013].
} 
respond when asked whether he had been tortured; the other detainees said that they had not. The reporter noted that he could not 'vouch for' the statements of the detainees. The broadcast continued with a description of how the Assad Government assigns blame to Jihadist/terrorist groups for the violence afflicting Syria, which provided a motive for the government to give the BBC access to 'alleged Jihadists'.

Arguably, each of the three broadcasts bears some 'news value' as each imparts information about aspects of the conflict in Syria. However, in addition to the obvious propaganda value that these 'interviews' provide to one side of the Syrian conflict, the nature and tone of the questions and comments in the $\mathrm{CNN}$ and $\mathrm{Al}$ Jazeera broadcasts imply the prisoners' responsibility for war crimes against civilians; an especially dangerous allegation to make, given their vulnerable position as captives of the FSA, and a charge which may not be correct. Similarly, the BBC broadcast depicts the 'confession' of detainees to involvement in terrorist organizations, a perilous acknowledgement to make by persons under the power of the Assad Government, and a potential justification for continued government human rights violations. ${ }^{32}$ Finally, the coercive conditions of each 'interview' with these detainees significantly weakens the credibility and value of the 'information' contained therein. Taken together, on balance these factors outweigh any 'news value' contained in these broadcasts.

\footnotetext{
${ }^{31}$ For a similar video 'interview' with prisoners/detainees held by the Syrian Ministry of Interior and 'awaiting trial', see T Marshall, 'Syria: Rebel Prisoners on Their Religious War', SkyNews, 8 December 2012, <http://news.sky.com/story/1022491/syria-rebel-prisoners-ontheir-religious-war> [accessed 26 July 2013].

${ }^{32}$ For example, in a particularly gruesome broadcast following the massacre of civilians in the city of Daraya, Al-Dunya journalist Micheline Azaz described how '[e]very time we enter an area with terrorists, they've already practiced what they preach. Criminality, killing, and all of it in the name of "freedom", 'Syrian TV “interviews" Orphan Beside Her Dead Mother', Al-Dunya TV, 28 August 2012, <http://www.youtube.com/watch?v=uRBnM8tmMuw\&feature=youtu.be > [accessed 26 July 2013].
} 


\section{The ethical duties of journalists pursuant to IHL and IHRL}

In times of armed conflict, ${ }^{33}$ the belligerent parties are bound to comply with the obligations of IHL. ${ }^{34}$ To date, standard interpretations of IHL have opined that it is the detaining power that has a positive legal obligation to treat prisoners and detainees humanely ${ }^{35}$ as opposed to other individuals-like journalists-who may have contact with detained persons. ${ }^{36}$ Thus, for example, international law expects that, in addition to members of the Syrian Government armed forces, all

${ }^{33}$ On 7 May 2012, the President of the International Committee of the Red Cross (ICRC) publicly announced that the ICRC had determined that in two parts of Syria, the Governorates of Homs and Idlib, the unrest had reached the level of a non-international armed conflict (NIAC) under international law. In these two specific locations, the ICRC believed that the legal criteria of intensity and duration of violence, plus the organizational level of the opposition armed groups known as the FSA, were present. Consequently, IHL applied throughout the territory of the Syrian State, 'and the safeguards afforded to persons deprived of their liberty in relation to the NIAC kick[ed] in regardless of the location of the detention facility'. D Cahen, 'Guest Post from the ICRC's Daniel Cahen Responding to My Post on Syria/LOAC', (Original Post by R Chesney), LawFare: Hard National Security Choices, 17 July 2012, <http://www.lawfareblog.com/2012/07/guest-postfrom-the-icrcs-daniel-cahen-responding-to-my-post-on-syrialoac/> [accessed 26 July 2013]. Until 7 May 2012, all parties to the conflict, as well as states, international institutions and NGOs monitoring Syria arguably could operate under the impression that international human rights law, rather than IHL, applied throughout Syria. Thus, the ability of the Syrian regime and its military and security forces to lawfully use lethal force against members of the opposition was quite limited. Given its stature as a leading arbiter of IHL questions, the ICRC's announcement changed the rules of the game in Syria, and all belligerent parties subsequently had the right to use lethal force against military targets. Thus, the parties to the Syrian conflict now had a duty to respect the rules of IHL, including the requirement that prisoners of war and others hors $d u$ combat be treated humanely. For a view challenging a strict reliance on the two legal criteria for the purpose of determining the application of IHL, see L R Blank \& G S Corn, 'Losing the Forest for the Trees: Syria, Law and the Pragmatics of Conflict Recognition' (2013) 46 Vanderbilt J Transnat'l L 3.

${ }^{34}$ Art 2 common to the GCs; Art 1(3) AP I; Art 1 AP II; ICRC Customary International Humanitarian Law Study, Rule 139, 'Respect for International Humanitarian Law' ('Each party to the conflict must respect and ensure respect for international humanitarian law by its armed forces and other persons or groups acting in fact on its instructions or under its direction or control') <http://www.icrc.org/customary-ihl/eng/docs/v1_cha_chapter40_rule139> [accessed 26 July 2013].

${ }^{35}$ ICRC, Commentary to Article 13 GC III, <http://www.icrc.org/ihl.nsf/COM/375-590017?Open Document $>$ [accessed 26 July 2013].

${ }^{36}$ The commentary to Common Article 3 of the GCs also refers to the obligations of the belligerent parties to armed conflict, as opposed to other entities or individuals. 'It is for the Parties to the conflict to conform to Article 3 and ensure the observance of all its provisions'. ICRC, Commentary to Article 3 GC III, <http://www.icrc.org/applic/ihl/ihl.nsf/vwTreaties1949.xsp> 
FSA commanders in Syria, be they an uneducated auto mechanic from Homs or a farmer from Idlib, will correctly apply the rules of IHL once the threshold criteria for an armed conflict exist. ${ }^{37}$

Although journalists are not 'parties' to armed conflict, they are important actors with the ability to influence events, military and civilian morale and the policies and decisions of governments. ${ }^{38}$ In Syria, for example, the Assad Government felt compelled to control domestic media outlets after the uprising began in March 2011. Agents of the regime harassed, detained, mistreated and/or interrogated a number of journalists who reported on the anti-government protests. ${ }^{39}$ The government confiscated televisions in military barracks as well as the cellular telephones of soldiers and army officers, thereby restricting their access to national and international news. ${ }^{40}$ The regime operates a State news channel and persons loyal to the Assad regime own all private television channels. ${ }^{41}$ Conversely, 'pro-opposition' television channels broadcast their information and messages into Syria from abroad. ${ }^{42}$ All of this activity confirms the media's potential to impact the behaviour of individuals and institutions, including, of course, persons responsible for the treatment of detainees.

Furthermore, legal philosopher Larry May argues that the tenets of IHL are

\footnotetext{
[accessed 26 July 2013].

${ }^{37}$ There is little doubt that, by the time of the October $2012 \mathrm{Al}$ Jazeera broadcast described above, the situation in Syria had degenerated into a full-blown civil war and was best classified as a non-international armed conflict for the purposes of IHL. S Nebehey, 'Red Cross Ruling Raises Questions of Syrian War Crimes', Reuters, 14 July 2012, <http://www.reuters.com/arti cle/2012/07/14/us-syria-crisis-icrc-idUSBRE86D09H20120714> [accessed 26 July 2013]. The question of whether assistance provided by third states to both the Assad Government and the Syrian opposition effectively transforms this crisis into an 'international' armed conflict is beyond the scope of this paper. See R Chesney, 'The War in Syria and LOAC: Some Key Issues', Lawfare: Hard National Security Choices, 15 July 2012, <http://www.lawfareblog.com/2012/07/thewar-in-syria-and-loac-some-key-issues/> [accessed 26 July 2013].

${ }^{38}$ D M Bishop, 'The Press and the TET Offensive: A Flawed Institution Under Stress' (1978) Air University Review, <http://www.airpower.maxwell.af.mil/airchronicles/aureview/1978/nov$\mathrm{dec} /$ bishop.html $>$ [accessed 26 July 2013].

${ }^{39}$ Human Rights Council, 'Report of the Independent International Commission of Inquiry on the Syrian Arab Republic', UN Doc A/HRC/S-17/2/Add.1, 23 November 2011, paras 88 and 104.

${ }^{40}$ Ibid, para 104.

${ }^{41}$ The government claims that its television station, al Ikhbariya, provides objective reporting. 'Inside the Syrian State TV Station', BBC NEWS, 11 February 2013, <http://www.guardian.co.uk/me $\mathrm{dia} / 2013 / \mathrm{feb} / 10 / \mathrm{bbc}$-documentary-syria-state-television> [accessed 26 July 2013].

${ }^{42}$ M Linstead, 'Syria's Media War: What You Need to Know', BBC NEWS, 20 October 2012, <http://www.bbc.co.uk/news/world-middle-east-20009357> [accessed 26 July 2013].
} 
expressions of primarily moral norms. ${ }^{43}$ If IHL is based on moral principles, it does not seem unreasonable to expect that all journalists-as well as editors and media executives who supervise journalists-learn and respect the basic moral principles that underlie the rules of IHL. ${ }^{44}$ The basic principles of IHL are 'elementary principles of humanity, even more exacting in peace than in war.' ${ }^{45}$ Moreover, the concept of humanity implies that 'each individual is desirous of the treatment corresponding to his status and can therefore judge how he should, in turn, treat his fellow human beings. ${ }^{46}$ Situations in life arise where moral duties and principles, a sense of justice and common sense compel certain conduct or omissions, regardless of the obligations imposed by legal rules. ${ }^{47}$ Thus, although journalists may not bear specific legal duties under IHL, common decency, morality and ethics should make any journalist very cautious about the use of 'interviews' of detained persons. ${ }^{48}$

One commentator suggested recently that perhaps the Geneva Conventions should be amended so that the prohibition against 'public curiosity' also applies 'to those who manufacture and distribute material that aids a government or non-state actors in the commission of crimes against POWs. ${ }^{49}$ A ban so broadly expressed, however, would be subject to multiple interpretations (including virtually any news report that suggests a degree of support or sympathy for a belligerent party) and could unfairly impinge on the right of the media to impart information and the right of the public to receive it. Moreover, the ICRC is presently revising its commentaries to the Geneva Conventions and the 1977 Additional Protocols. ${ }^{50}$ Thus, it may be more effective to insert a specific

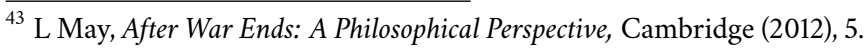

${ }^{44}$ Meyer and Studds, above n 5, 3 (suggesting that to be most effective, as reporters and as entities that can help to ensure respect for IHL, journalists who report on armed conflicts would benefit from a greater understanding of IHL).

${ }^{45}$ Corfu Channel (United Kingdom of Great Britain and Northern Ireland v Albania), Judgment, ICJ Reports 1949, p 4, 22.

${ }^{46}$ ICRC, Commentary to Article 13(1) GC III, <http://www.icrc.org/ihl.nsf/COM/375-590017?Ope nDocument> [accessed 26 July 2013].

${ }^{47}$ G Radbruch, 'Statutory Lawlessness and Supra-Statutory Law (1946)', (2006) 26 Oxford JLS 1, 1-8.

${ }^{48}$ S J Frantzman, 'Terra Incognita: The Media and War Crimes', Jerusalem Post, 24 October 2012, <http://www.jpost.com/Opinion/Columnists/Terra-Incognita-The-media-and-warcrimes $>$ [accessed 26 July 2013]. The protection of prisoners against intimidation, insults and public curiosity represents moral values as well legal obligations. ICRC, Commentary to Article 13, GC III, above n 35 .

${ }^{49}$ Frantzman, ibid.

${ }^{50}$ ICRC, 'Bringing the Commentaries on the Geneva Conventions and the Additional Protocols to the Twenty-first Century', Interview with J-M Henckaerts, 13 December 2012, 
admonishment in the text of the commentaries about the exploitation of detained persons by members of the media or other individuals not directly associated with a party to the armed conflict.

Such an admonishment would be consistent with the practice of the British military, which, while permitting video and still-photography of detainees to illustrate the scale and nature of capture, usually will not permit interviews with prisoners by the media or 'close-up' photography that concentrates on individual detainees. ${ }^{51}$ Ministry of Defence staff attempt to balance the need for journalists to report on prisoners of war 'prudently and discretely' with concerns about the effect of publication or transmission of information on detainees or their families. ${ }^{52}$ Similarly, prior to the March 2003 invasion of Iraq, the U.S. Department of Defence prohibited 'embedded' journalists from taking photographs of the faces of enemy prisoners of war or detainees, as well as interviews with persons in custody. 53

IHRL is also in force during armed conflict. The United Nations Security Council, the General Assembly and the Human Rights Council have affirmed the applicability of IHRL to situations of armed conflict in hundreds of separate resolutions. ${ }^{54}$ Furthermore, the jurisprudence of the International Court of Justice observes that both IHL and IHRL apply during armed conflict, although IHL serves as the lex specialis. ${ }^{55}$

<http://www.icrc.org/eng/resources/documents/interview/2012/geneva-conventions-comme ntaries-interview-2012-07-12.htm > [accessed 26 July 2013].

${ }^{51}$ Ministry of Defence,'Green Book', above n 18, 18.

${ }^{52}$ Ibid.

${ }^{53}$ United States Secretary of Defence, 'Memorandum: Public Affairs Guidance on Embedding Media During Possible Future Operations/Deployments in the U.S. Central Commands', February 2003, paras 4.G.18 and 4.G.19, <http://www.fas.org/sgp/othergov/dod/embed.html> [accessed 26 July 2013].

${ }^{54}$ I Siatitsa \& M Titberidze, 'Human Rights in Armed Conflict from the Perspective of the Contemporary State Practice in the United Nations: Factual Answers to Certain Hypothetical Challenges', Rule of Law in Armed Conflicts Project, Geneva Academy of International Humanitarian Law and Human Rights, 34, <http://www.geneva-academy.ch/RULAC/inter action_between_humanitarian_law_and_human_rights_in_armed_conflicts.php> [accessed 26 July 2013].

${ }^{55}$ Legal Consequences of the Construction of a Wall in the Occupied Palestinian Territory, Advisory Opinion, ICJ Reports 2004 p 136, para 106. Acts and omissions may implicate international law. For example, in its Judgment in Case Concerning Armed Activities on the Territory of the Congo, the International Court of Justice found Uganda responsible not only for the acts of its military that violated international obligations in areas of the Democratic Republic of Congo under its occupation, but also for 'any lack of vigilance in preventing violations of human rights and IHL by other actors present in the occupied territory, including rebel groups acting on their own account'. Case Concerning Armed Activities on the Territory of the Congo (Democratic Republic of 
The relationship between these two bodies of law and the duties required by them during armed conflict 'remains quite complex'. ${ }^{56}$ IHL and IHRL can complement and reinforce each other, although at times IHL will specify the applicable rules and their interpretation, while in other cases it will be IHRL, depending on which body of law is more detailed and adapted to the situation. ${ }^{57}$ When necessary, any restrictions on particular human rights (in this case, the media's freedom of expression) should be proportionate to the legitimate IHL objective at stake. ${ }^{58}$

As in the case of the law of armed conflict, traditional interpretations of IHRL do not impose legal obligations on journalists. 'In practical terms, human rights ... arise against the state, which so far has a virtual monopoly of responsibility' ${ }^{59}$

Nevertheless, IHRL and the moral principles that support it, protects the dignity inherent in all human beings and forbids all forms of exploitation and degrading treatment. ${ }^{60}$ This should include, of course, any abuse or exploitation of prisoners of war or other persons detained during armed conflict. Indeed, with respect to the 'interviews' of detainees in the broadcasts described in this article, the principles underlying IHL and IHRL reinforce each other. Thus, a more liberal view of IHRL suggests that journalists bear at least an ethical duty to ensure that their conduct does not, in any way, undermine the inherent right to dignity owed to detained persons. Arguably, in each of the three news broadcasts from Syria described above, the participating journalists did not fulfil this duty.

\section{Application of international law's protections of prisoners of war and other detained persons}

A strong argument can be made that the February 2012 CNN broadcast described above was a violation of the spirit (if not the letter) of IHL and IHRL. CNN clearly made the detainee an object of public curiosity and the fact that the captive was wounded only increased the likelihood that his captors took advantage of

Congo v Uganda), Judgment, ICJ Reports 2005, p 168, para 179.

56 'Interaction Between Humanitarian Law and Human Rights in Armed Conflicts', Rule of Law in Armed Conflicts Project, Geneva Academy of International Humanitarian Law and Human Rights, <http://www.geneva-academy.ch/RULAC/interaction_between_humanitarian_law_and_human_rights_in_armed_conflicts.php> [accessed 26 July 2013].

57 Ibid.

${ }^{58}$ Open Door Counseling and Dublin Well Woman v. Ireland, [1992] ECHR 14235/88, para 70.

${ }^{59} \mathrm{~J}$ Crawford, Brownlie's Principles of Public International Law (1998) 121.

${ }^{60}$ Art 7 and 10 ICCPR; Art 3 ECHR; Art 1 and 5 Universal Declaration of Human Rights (UDHR). 
his weakness to exploit him for propaganda purposes. ${ }^{61}$ The CNN journalist herself acknowledged that she could not verify whether the man was coerced into providing the information, but this circumstance did not stop her from performing her 'interview' nor did it stop CNN from broadcasting the material with the knowledge that the status of the detainee as a 'bargaining chip' made him a likely subject of propaganda. We will probably never know the fate of this man, whether the information attributed to him was true or not, or whether this broadcast had consequences for his safety and/or the safety of his family or others in Syria. In this case, however, the journalist and CNN violated the moral principles underlying IHL and IHRL in order to produce a 'news' story.

A closer look at the CNN broadcast, however, reveals circumstances that might justify its production and release, based on the overriding IHL principle of humanity and IHRL's fundamental right to life. The reporter explains, somewhat confusingly, that the detainee 'asked that his identity be obscured enough so that the government can't recognize him, but said that he wanted his friends to know that he is alive-and a changed man'. ${ }^{62}$ A number of interests appear to be expressed in this ambivalent and contradictory statement. First, the man does not want the Government to see him as a 'traitor' to the cause of the Syrian state. Second, he wants some members of his community to know that he is detained, perhaps so that they could take action on his behalf. Lastly, but perhaps most importantly given his vulnerable, captive condition, the man wants to distance himself from his alleged violent past. Through this lens, what appears at first blush to be an improper use of a detainee as a 'public curiosity', begins to develop into strategies and efforts intended to protect the man's life. ${ }^{63}$ The man once thought that members of the Syrian opposition were terrorists; now the thinks differently' ${ }^{64}$ Since he was detained, however, 'I have seen only good'. ${ }^{65}$

Nevertheless, any attempt to protect the man's interest in this broadcast would have been much better served without the inclusion of his (possibly

\footnotetext{
${ }^{61}$ As depicted in another, horrific video posted recently on Youtube apparently depicting the execution of a group of prisoners by the FSA, detained persons in Syria and wounded prisoners in particular, are extremely vulnerable to abuse. 'Syrian Rebels Massacre 11 Prisoners in Saraqib, Syria, <http://www.youtube.com/watch? $\mathrm{v}=\mathrm{t} 5 \mathrm{OLmnYpIXs \& feature=end}$ screen\&NR=1\&oref=http\%3A\%2F\%2Fwww.youtube.com\%2Fwatch\%3Fv\%3Dlvp1HXjXWIs\&ha s_verified $=1 \& b p c t r=1352290880>$ [acccessed 26 July 2013].

62 'A Paid Killer in Syria Describes His Work', above n22, 00:00:20-28 seconds.

${ }^{63} \mathrm{I}$ am grateful to Heathcliff O'Malley for helping me to develop this point.

64 'A Paid Killer in Syria Describes His Work,' above n22, 00:02:05-00:02:09.

${ }^{65}$ Ibid, 00:02:15-00:02:20.
} 
coerced) 'confession', including the man's 'chilling'66 story about how he killed unarmed protesters and how he once slit another detainee's throat. The public's interest in receiving this information would seem to be diluted (if not erased) by the likelihood that the captive's statement: 1) may have been coerced, 2) may be untrue, and 3) may place him in even greater danger.

Circumstances may arise where the publication of information in the media about prisoners and/or detainees may be beneficial to their interests, and to the public interest. ${ }^{67}$ For example, the 1992 press photographs of emaciated detainees standing behind barbed wire in the town of Prijedor, Bosnia and Herzegovina, cast the world's attention on the operation of concentration camps by Bosnian Serb forces and the plight of non-Serbs incarcerated there. In August 2012, FSA forces permitted the New York Times' Brian Denton to photograph one of their captives, a 'mentally damaged' member of a Government paramilitary unit, with evident bruises and swollen limbs apparently resulting from the torture he had received from his FSA captors. ${ }^{68}$ There is a distinct difference, however, between a still photograph or video material that depicts the reality of harsh detention conditions and an 'interview' that extracts information from a detainee which 1) may be false and 2) may place that person and others in danger. The former can save prisoners' lives. The latter constitutes abuse. The humanity principle underlying IHL and the value of human dignity central to IHRL may call for different judgements in different situations; but it should not permit the exploitation or endangerment of protected persons.

Nevertheless, 'public curiosity' about world events drives many persons to seek out and receive news. ${ }^{69}$ For example, in the context of the Syria conflict, renowned English war photographer Don McCullin left his comfortable life in retirement to spend a week in the ravaged city of Aleppo 'to show the human toll of the fighting. ${ }^{70}$ This dynamic, one source for the marketplace of ideas that sustains any democracy, may increase the public interest value of depicting prisoners of war in media broadcasts.

\footnotetext{
${ }^{66} \mathrm{Ibid}, 00: 00: 55-57$.

${ }^{67}$ Meyer \& Studds, above n 5, 3 .

${ }^{68}$ According to the report, the FSA subsequently attempted to force the prisoner to drive a truck bomb to a Syrian army checkpoint. Their plot failed when the bomb failed to detonate remotely and Government forces detained the prisoner. 'Syria's Agony: The Photographs that Moved Them Most', 10 December 2012, <http://lightbox.time.com/2012/12/10/photographing-syriasagony-the-images-that-moved-them-most/?iid=lb-gal-moreon\#17> [accessed 26 July 2013].

${ }^{69}$ I am grateful to Frank Smyth for this point.

70 'War Photographer Don McCullin in Final Front-line Trip', BBC News Middle East, 13 December 2012, <http://www.bbc.co.uk/news/world-middle-east-20710432> [accessed 26 July 2013].
} 
Commentators such as Meyers and Studds have suggested, however, that as a matter of principle, IHL's ban on subjecting detainees to public curiosity trumps freedom of expression concerns to such an extent that any broadcast/publication of a film/photo of an identifiable prisoner of war or detainee should normally be prohibited. ${ }^{71}$ Similarly, they argue that the publication of photos of unrecognisable prisoners in humiliating or degrading positions would also be impermissible. $^{72}$ In my view, these positions are too extreme in that they effectively codify a 'conflict' between IHL and IHRL rather than finding a way to harmonise divergent laws. Meyers and Studds give insufficient weight to the potential humanitarian value of the publication of such material. The mere broadcast of an identifiable prisoner of war or detainee, may, depending on the circumstances, save that person's life. Moreover, photos of unidentifiable degraded and humiliated prisoners-such as those from Abu Ghraib prison in Iraq-may stimulate sufficient public concern and pressure so that the relevant authorities cease the abusive behaviour. Conceivably, this kind of media attention also can empower the victims of such mistreatment to re-assert their own rights. ${ }^{73}$ Thus, the 'principle' enunciated by Meyers and Studds gives insufficient weight to the benefits of publicizing such information, and fails to properly balance the interests of IHL and the important IHRL value of freedom of expression that are at stake.

The question remains with respect to persons detained by parties to an armed conflict, what criteria should be used to determine when the public interest to impart and receive information trumps international law's protections against making detainees objects of public curiosity and other degrading treatment? ${ }^{74}$ One common-sense response may assist journalists to answer this question: when it is reasonable to believe that publication of the detainee's face, identity and/or other information may assist his/her safety and well-being, and not

${ }^{71}$ Meyer \& Studds, above n 5, 3.

72 Ibid.

${ }^{73}$ H Shue, Basic Rights (1980) 167.

${ }^{74}$ It will not be legally or ethically sufficient for captors to declare during the broadcast of an interrogation that their prisoner(s) will be treated according to the standards of the Geneva Conventions. For example at the end of one video attached to a Washington Post article about a Syrian Air Force pilot captured by the FSA in August 2012, an FSA commander made such a statement after interrogating the detainee on-camera, in violation of IHL, and inducing the pilot to call on his fellow military officers to 'defect away from that gang'. B Dehghampisheh, 'Syria Rebels Claim Shoot-Down of Fighter Jet: Government Disputes Report', The Washington Post, 13 August 2012, <http://www.washingtonpost.com/world/mid dle_east/syria-rebels-claim-shootdown-of-fighter-jet-government-disputes-report/2012/08/13 /49986654-e572-11e1-936a-b801flabab19_story.html?wpisrc=emailtoafriend> [accessed 26 July 2013]. 
lead to exploitation or abuse. Put more starkly, journalists and their editors and employers might ask themselves: 'Will this broadcast help or damage the humanitarian interests of the detainee(s)? 75

By contrast, in situations of likely duress and coercion, broadcasts of 'interviews' and 'confessions' produce confusion rather than information, particularly given, in one journalist's words: 'the difficulty of verifying anything' in Syria. ${ }^{76}$ For example, all three of the journalists reporting in the media broadcasts described in this article felt it necessary to distance themselves from the reliability of the detainees' statements: 'There's no way to confirm [his] story. Or be sure he hasn't been coerced." 77 'We had no way to establish exactly how he had been treated before we got there, or what kinds of pressure he was under.' ${ }^{\text {' }}$ 'I can't vouch for what they said. ${ }^{79}$ Thus, the detainees' humanitarian interests may outweigh the public's interest in the production and dissemination of these kinds of broadcasts. Furthermore, such broadcasts by major media outlets such as $\mathrm{CNN}, \mathrm{Al}$ Jazeera and the BBC will encourage 'media savvy' ${ }^{80}$ belligerent parties holding captives to mount (or 'parade' as in the BBC's term) more propaganda exercises using exploited detainees. ${ }^{81}$

In cases of doubt, a safer methodology might be for journalists to insist on solely photographing and/or filming prisoners of war and their identity documents, without recording additional information. This would assist detainees by ensuring that a record exists of their captivity, without subjecting them to questionable interrogation techniques. Some might argue that this strategy would unduly reduce the 'news value' or public interest of a particular report. This seems like a specious argument, however, as any depiction of the lives and circumstances of persons detained during armed conflict would seem to have inherent 'news value' and public interest. Furthermore, this methodology would serve as a precedent for the protection of detained or arrested journalists who could insist upon equal treatment.

As a profession, journalists are well-aware of the dangers facing prisoners of

\footnotetext{
${ }^{75}$ My thanks to Frank Smyth for helping me to clarify this point.

${ }^{76} \mathrm{~J}$ Vela, 'The Most Dangerous Beat on Earth: Four Journalists Weigh In on What It's Like to Cover Syria,', Foreign Policy, 20 December 2012, <http://www.foreignpolicy.com/artic les/2012/12/18/the_most_dangerous_beat_on_earth?page=0,1> [accessed 26 July 2013].

77 'A Paid Killer In Syria Describes His Work', above n 22, 00:02:31-00:02:36.

78 'Captured Syrian Pilot Speaks to Al Jazeera', above n 24, 00:00:41-00:00:48 (emphasis added).

79 'Syria Rebel-Held Areas Fear Attack', above n 28, 00:02:26-00:02:28.

${ }^{80}$ Vela, above $\mathrm{n} 76$.

${ }^{81}$ See A Barnard, 'Syria Playing on Fears of Jihad', International Herald Tribune, 25 April 2013, 1 and 6.
} 
war or other persons detained during armed conflict. For example, in December 2012, the journalist advocacy and protection organization Reporters Without Borders issued a news release expressing its concern for the fate of Ukrainian journalist Anhar Kochevna, allegedly held for ransom in Syria by members of the FSA. Arrested journalists, the group noted, 'should be treated humanely, or charged, or released'. ${ }^{82}$ However, two videos of Ms. Kochevna had appeared on the internet in which she 'confessed' to serving as a military interpreter for Syrian and Russian officers. Reporters Without Borders noted that it was 'deeply concerned that in both video appeals the journalist seems to be speaking under pressure. ${ }^{83}$ Journalists in conflict zones should extend these same concerns to the prisoners of war with whom they have contact, for the security of the detainees and for their own.

Even in today's era of 24/7 news, cable television, internet media and Youtube, the press, individually and institutionally, can modify its behaviour when it believes that restraint is in its interests. For example, after Shabiha militia members allied with the Assad Government kidnapped NBC correspondent Richard Engel and his crew in Syria, a video of the captured men appeared on Youtube and news of their predicament appeared in other media outlets. ${ }^{84}$ However, Youtube quickly removed the video and, at the urging of NBC News, most Western media outlets maintained a 'blackout' on the story in order to assist persons in Syria attempting to locate the kidnapped men. ${ }^{85}$ Thus, one effective way to ensure that media work remains consistent with the moral principles underlying international law would be to generate a change in media culture, whereby journalists, their colleagues and supervisors would come to view

${ }^{82}$ Reporters Without Borders, 'Threat of Imminent Execution of Kidnapped Ukrainian Journalist', 13 December 2012, <http://en.rsf.org/syria-threat-of-imminent-execution-of12-12-2012,43785.html > [accessed 26 July 2013].

83 Ibid.

84 'Video Shows NBC's Richard Engel and Crew Held by Assad Loyalists', Brown Moses Blog, 18 December 2012, <http://brown-moses.blogspot.co.uk/2012/12/video-shows-nbcs-richard-engeland-crew.html> [accessed 26 July 2013].

${ }^{85}$ Ibid; D Murphy, 'Richard Engel Freed, But News Blackout Debate Remains', The Christian Science Monitor, 18 December 2012, <http://www.csmonitor.com/World/Backchannels/2012/1218/Richard-Engel-freed-but-news-blackout-debate-remains?cmpid=ad-

dthis_email\#.UNFsu3PSh0A.email> [accessed 26 July 2013]; H Chua-Eoan, 'Journalists at Risk: How and NBC Correspondent Emerged from Syrian Captivity', Time, 18 December 2012, <http://world.time.com/2012/12/18/journalists-at-risk-how-an-nbc-correspondent-emergedfrom-syrian-captivity/> [accessed 26 July 2013]. Also see 'American Journalist Missing in Syria', Associated Press, 2 January 2013, http://bigstory.ap.org/article/american-journalist-missing-syria [accessed 26 July 2013]. 
appropriate limits on the content of broadcasts of prisoners of war as serving, rather than harming, their own interests.

\section{Possible solutions to reduce confusion for journalists and the potential for abuse of detainees}

Journalists in war zones and editors and publishers who review their material should carry the Geneva Conventions and Additional Protocols as a tool to assist them to protect the dignity of other vulnerable persons who deserve the benefits of international law. It is not my intention to advocate for limitations on freedom of expression. ${ }^{86}$ However, the right to receive and impart information carries with it certain duties and responsibilities. ${ }^{87}$ Thus, if journalists expect to receive the protections that IHL and IHRL accords them, professional ethics and common decency should require them to perform their work without violating the moral principles that support the law. The following seven recommendations may help to ensure compliance with international law:

1. The amended ICRC commentaries to the Geneva Conventions should include a clear admonishment against the exploitation of detainees by members of the media or others not directly associated with a party to an armed conflict;

2. Prior to their deployment, sufficient instruction in the principles and rules of IHL should be provided to all journalists who cover armed conflicts (or situations of protracted violence that may not meet the legal threshold of an armed conflict) so that they do not exploit prisoners or assist in their exploitation;

\footnotetext{
${ }^{86}$ See generally Inter-American Commission of Human Rights, 'Declaration on Freedom of Expression' (2011) <http://www.oas.org/en/iachr/expression/showarticle.asp?artID=26\&IID=1> [accessed 26 July 2013]; Art 13 American Convention on Human Rights, 22 November 1969, 1144 UNTS 143; Art 19 UDHR; Art 9 African Charter.

${ }^{87}$ Art 19 ICCPR (holding that the exercise of the rights of freedom of expression, to seek, receive and impart information carries with it special duties and responsibilities, for example, to respect the rights or reputations of others); Art 10(2) ECHR (holding that the exercise of the freedom of expression and to receive and impart information carries with it duties and responsibilities, for example, to protect the health, reputation or rights of others or for preventing the disclosure of information received in confidence).
} 
3. If journalists have any contact with prisoners of war or other detained persons, it should be limited, if requested by the detainees, to recording their names and faces. Journalists and/or media companies should never disseminate material that treats captives as objects of 'public curiosity' or places them, or their families and associates, at greater risk;

4. Journalists should never meet with or 'interview' prisoners of war with their captors present, as this only increases the risk of pressure and coercion on the prisoner, and the likelihood that the journalist will receive false information;

5. Major news outlets should retain legal advisers who will be available to address international law issues presented by the work of journalists in the field, just as militaries use legal advisers to review and address legal issues that arise during the operations of their forces; ${ }^{88}$

6. Media outlets who cover armed conflicts should produce their own guidelines to prevent the broadcast of videos or the publication of reports that treat captives as objects of 'public curiosity' or place them, or their families and associates, at greater risk; ${ }^{89}$ and

7. Media outlets should pledge never to publish reports that violate rules of IHL, IHRL and/or principles of humane treatment towards detained persons.

Adherence to these proposals would reduce the risk that belligerent parties to an armed conflict view journalists as propaganda tools of one side to the hostilities. Thus, in addition to ensuring that detained persons are protected from exploitation and other forms of humiliating or dangerous treatment, these measures also would improve the safety of journalists in the field. ${ }^{90}$ Finally, these recommendations might assist journalists and other media professionals to find the right balance between the freedom of expression and IHL's protections of persons detained by a party to an armed conflict.

${ }^{88}$ Art 82 AP I.

${ }^{89}$ Frantzman, above $\mathrm{n} 48$.

90 The security risks for foreign journalists have received greater attention during recent years, in part due to the deaths and detention of journalists in Syria. See Global Journalist Security, <http://www.journalistsecurity.net/team/> [accessed 26 July 2013]. 
Syria is a 'uniquely dangerous environment' ${ }^{\text {'1 }}$ for journalists reporting on the conflict, requiring difficult judgements about the methods and content of news reports. Syria is also, of course, an exceptionally dangerous place to be a detainee. Nevertheless, it is possible for journalists, even in Syria, to inform the public about the existence of detained persons, as well as their locations and general conditions, without contributing to the exploitation of these individuals for the benefit of their captors, the journalists, or both. Journalists can perform an invaluable service by locating, mapping and reporting about where detained persons are being held and by whom. Better training, more professionalism, greater clarity in the law and a change in media culture, however, are needed to avoid the situations of mistreatment and exploitation of detainees in Syria described in this article.

\footnotetext{
${ }^{91}$ P Conroy, 'Syria: The Most Dangerous Beat on the Earth', <http://www.post-gazette.com/storie s/opinion/perspectives/syria-the-most-dangerous-beat-on-earth-four-journalists-describe-wh at-its-like-to-cover-the-syrian-civil-war-667463/> [accessed 26 July 2013].
} 